\title{
Assessment of Undiscovered Continuous Oil and Gas Resources in the Domanik-Type Formations of the Volga-Ural Region Province, Russia, 2017
}

Using a geology-based assessment methodology, the U.S. Geological Survey estimated mean undiscovered, technically recoverable continuous resources of 2.8 billion barrels of oil and 34 trillion cubic feet of gas in the Domanik-type formations of the Volga-Ural Region Province, Russia.

\section{Introduction}

The U.S. Geological Survey (USGS) quantitatively assessed the potential for undiscovered, technically recoverable continuous oil and gas resources in the Volga-Ural Region Province of Russia (fig. 1). This study focused on the geologic evaluation and assessment of oil and gas source-reservoir rock systems (petroleum systems) and potential resources of the Upper Devonian-Lower Carboniferous (Tournaisian) Domanik-type formations. These include the Domanik Formation and Domanikoids (younger rocks overlying the Domanik Formation).

For this assessment, the USGS defined continuous oil and gas systems that (1) contain at least 2 weight percent or more total organic carbon, (2) occur within the thermal maturity window for oil or natural gas generation, (3) have thick (15 meters or more) organic-rich shale, and (4) contain Type I or Type II organic matter (Charpentier and Cook, 2011). Many studies have been published on the Domanik-type formations, providing information on sourcerock characteristics, tectonic history, thermal history, and timing of the maturation and generation of hydrocarbons (Zaydelson and others, 1991; Fadeeva and others, 2016). Several conventional oil and some gas fields or accumulations have been discovered in the Volga-Ural region that produce from reservoirs, commonly in structural traps and reefs (Ulmishek, 1988). Reports on the number of wells that produce directly from Domanik-type formations but not from conventional accumulations were unavailable for this study.

The Domanik Total Petroleum System and three assessment units (AUs) were defined for this assessment (fig. 1). The Domanik Formation Continuous Oil AU was delineated over much of the eastern part of the province. The Domanik Formation source rock was deposited during a maximum transgression of sea level during the Late Devonian (early Frasnian) above older nearshore sediments (Ulmishek, 1988). The Domanikoid Continuous Oil AU was deposited above the Domanik Formation in elongated areas (troughs) between reefs and carbonate platforms. The Domanikoid Continuous Oil AU is younger than the Domanik Formation Continuous Oil AU (Peterson and Clarke, 1983). Both the Domanik Formation Continuous Oil and Domanikoid Continuous Oil AUs are thermally mature with respect to oil generation. The Domanik Formation Foredeep Continuous Gas AU was delineated in the eastern part of the region in a foredeep basin along the Ural Mountains where the Domanik source rock is deeper and presumably thermally mature with respect to gas generation.

Detailed production data for continuous resources outside of the United States are difficult to obtain, so the USGS assessment methodology uses production data of continuous oil and gas accumulations from the United States, which serve as analogs. Specifically, mean estimated ultimate recoveries from populations of continuous oil and gas wells, the mean drainage areas of drilled wells, and ranges of average well success ratios were used to estimate undiscovered continuous oil and gas resources. Principal input data used in the assessment are listed in table 1.

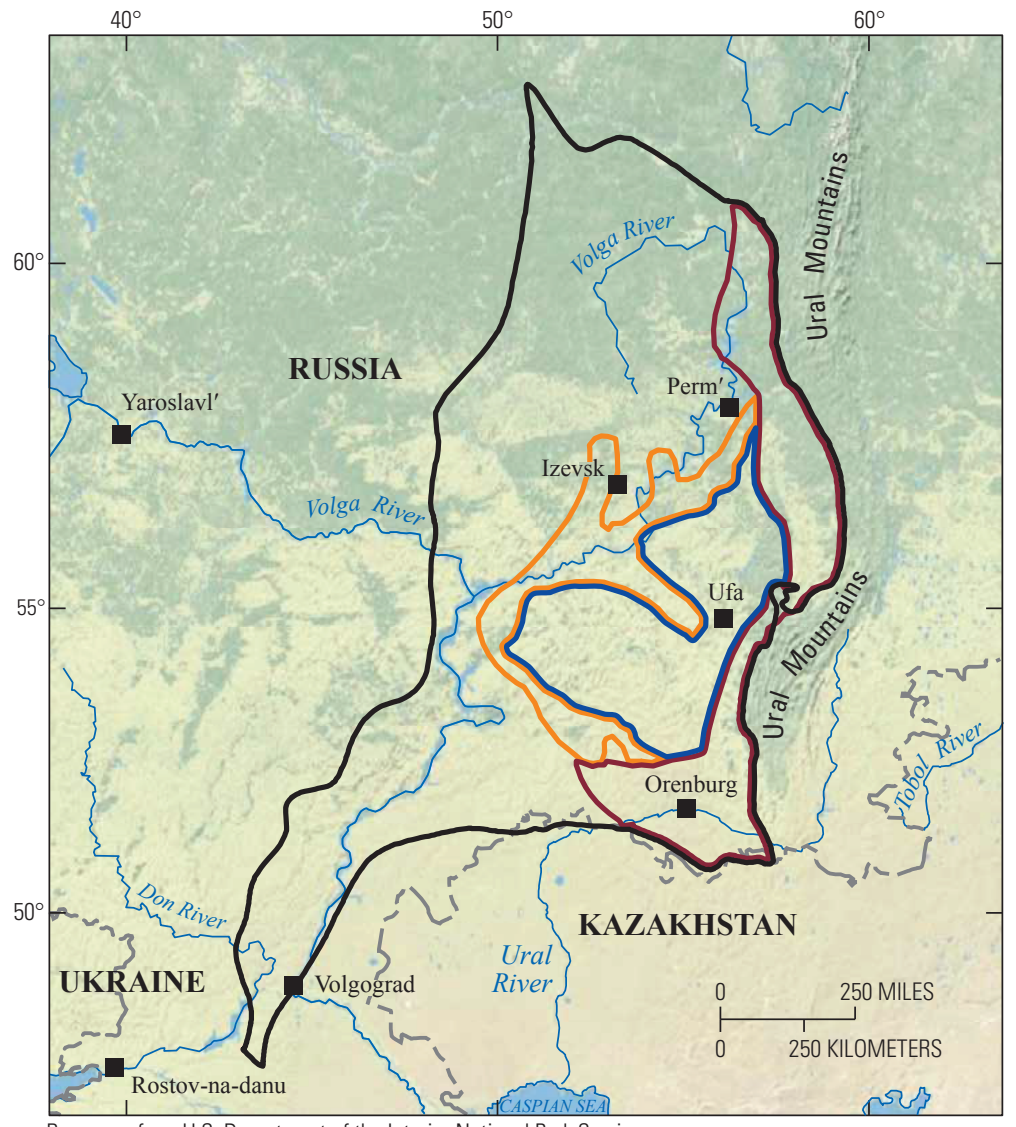

Base map from U.S. Department of the Interior National Park Service

\section{EXPLANATION}
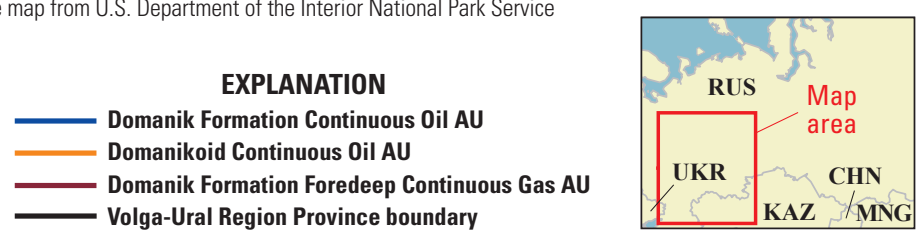

Figure 1. Location of the three assessment units (AUs) in the VolgaUral Region Province, Russia.

\section{Geologic Model}

Continuous oil production has been reported from the fractured Domanik Formation in the southern part of the basin. The Domanik Formation is a self-sourced, organic-rich mudstone (total organic carbon content of at least 2 weight percent); contains mostly Type II kerogen; and is thermally mature with respect to oil generation (Ulmishek, 1988). Undiscovered continuous oil accumulations most likely exist between structural highs. The Domanik Formation 
Continuous Oil AU area does not include areas of discovered conventional fields (and [or] accumulations).

No continuous gas production has been reported from the Domanik Formation Continuous Oil AU or Domanikoid Continuous Oil AU. The Domanik Formation Foredeep Continuous Gas AU is thermally mature with respect to gas generation, but few gas fields have been discovered. Undiscovered continuous gas accumulations most likely exist between structural highs. The Domanik Formation Foredeep Continuous Gas AU area does not include areas of discovered conventional fields on structural highs.

\section{Undiscovered Resources Summary}

The USGS quantitatively assessed oil and gas resources in three AUs in the Volga-Ural Region Province of Russia (table 2). For undiscovered, technically recoverable oil and gas resources, the estimated means are 2,787 million barrels of continuous oil (MMBO), or 2.8 billion barrels of oil, with an F95-F5 range from 663 to 6,072 MMBO; 33,558 billion cubic feet of natural gas (BCFG), or 34 trillion cubic feet of natural gas, with an F95-F5 range from 7,823 to 71,455 BCFG; and 1,343 million barrels of natural gas liquids (MMBNGL) with an F95-F5 range from 308 to 2,884 MMBNGL.

Table 1. Key assessment input data for three continuous assessment units in the Volga-Ural Region Province, Russia.

[AU, assessment unit; \%, percent; EUR, estimated ultimate recovery per well; MMBO, million barrels of oil; BCFG, billion cubic feet of gas. The average EUR input is the minimum, median, maximum, and calculated mean. Shading indicates not applicable]

\begin{tabular}{|c|c|c|c|c|c|c|c|c|}
\hline \multirow[b]{2}{*}{ Assessment input data - Continuous AUs } & \multicolumn{4}{|c|}{ Domanik Formation Continuous Oil AU } & \multicolumn{4}{|c|}{ Domanikoid Continuous Oil AU } \\
\hline & Minimum & Mode & Maximum & $\begin{array}{c}\text { Calculated } \\
\text { mean }\end{array}$ & Minimum & Mode & Maximum & $\begin{array}{c}\text { Calculated } \\
\text { mean }\end{array}$ \\
\hline Potential production area of AU (acres) & 1,000 & $15,936,500$ & $31,873,000$ & $15,936,833$ & 1,000 & $7,484,000$ & $14,967,000$ & $7,484,000$ \\
\hline Average drainage area of well (acres) & 120 & 180 & 240 & 180 & 120 & 180 & 240 & 180 \\
\hline Success ratio $(\%)$ & 10 & 30 & 70 & 36.7 & 10 & 25 & 60 & 31.7 \\
\hline Average EUR (MMBO) & 0.03 & 0.06 & 0.15 & 0.065 & 0.02 & 0.05 & 0.1 & 0.052 \\
\hline AU probability & 1.0 & & & & 1.0 & & & \\
\hline \multirow[b]{2}{*}{ Assessment input data - Continuous AU } & \multicolumn{4}{|c|}{ Domanik Formation Foredeep Continuous Gas AU } & & & & \\
\hline & Minimum & Mode & Maximum & $\begin{array}{c}\text { Calculated } \\
\text { mean }\end{array}$ & & & & \\
\hline Potential production area of AU (acres) & 1,000 & $14,755,000$ & $29,510,000$ & $14,755,333$ & & & & \\
\hline Average drainage area of wells (acres) & 80 & 120 & 160 & 120 & & & & \\
\hline Success ratio $(\%)$ & 10 & 50 & 90 & 50 & & & & \\
\hline Average EUR (BCFG) & 0.2 & 0.5 & 1.0 & 0.522 & & & & \\
\hline AU probability & 1.0 & & & & & & & \\
\hline
\end{tabular}

Table 2. Assessment results for three continuous assessment units in the Volga-Ural Region Province, Russia.

[MMBO, million barrels of oil; BCFG, billion cubic feet of gas; NGL, natural gas liquids; MMBNGL, million barrels of natural gas liquids. Results shown are fully risked estimates. For gas accumulations, all liquids are included in the NGL category. F95 represents a 95-percent chance of at least the amount tabulated; other fractiles are defined similarly. Fractiles are additive under the assumption of perfect positive correlation. Shading indicates not applicable]

\begin{tabular}{|c|c|c|c|c|c|c|c|c|c|c|c|c|c|c|}
\hline \multirow{3}{*}{$\begin{array}{l}\text { Total petroleum system and } \\
\text { assessment units (AUs) }\end{array}$} & \multirow{3}{*}{$\begin{array}{c}\text { AU } \\
\text { prob- } \\
\text { ability }\end{array}$} & \multirow{3}{*}{$\begin{array}{c}\text { Accumu- } \\
\text { lation } \\
\text { type }\end{array}$} & \multicolumn{12}{|c|}{ Total undiscovered resources } \\
\hline & & & \multicolumn{4}{|c|}{ Oil (MMBO) } & \multicolumn{4}{|c|}{ Gas (BCFG) } & \multicolumn{4}{|c|}{ NGL (MMBNGL) } \\
\hline & & & F95 & F50 & F5 & Mean & F95 & F50 & F5 & Mean & F95 & F50 & F5 & Mean \\
\hline \multicolumn{15}{|c|}{ Domanik Total Petroleum System } \\
\hline Domanik Formation Continuous Oil AU & 1.0 & Oil & 494 & 1,831 & 4,599 & 2,098 & 236 & 899 & 2,364 & 1,049 & 9 & 35 & 98 & 42 \\
\hline Domanikoid Continuous Oil AU & 1.0 & Oil & 169 & 612 & 1,473 & 689 & 81 & 300 & 757 & 344 & 3 & 12 & 32 & 14 \\
\hline Domanik Formation Foredeep Continuous Gas AU & 1.0 & Gas & & & & & 7,506 & 28,875 & 68,334 & 32,165 & 296 & 1,145 & 2,754 & 1,287 \\
\hline Total undiscovered continuous resources & & & 663 & 2,443 & 6,072 & 2,787 & 7,823 & 30,074 & 71,455 & 33,558 & 308 & 1,192 & 2,884 & 1,343 \\
\hline
\end{tabular}

\section{References Cited}

Charpentier, R.R., and Cook, T.A., 2011, USGS methodology for assessing continuous petroleum resources: U.S. Geological Survey Open-File Report 2011-1167, 73 p., accessed September 26, 2016, at http://pubs.usgs.gov/of/2011/1167/.

Fadeeva, N.P., Kozlova, E.V., Poludetkina, E.N., Shardanova, T.A., Pronina, N.V., Stupakova, A.V., Kalmykov, G.A., and Khomyak, A.N., 2016, The hydrocarbon-generation potential of the Domanik rocks in the Volga-Ural petroliferous basin: Moscow University Geology Bulletin, v. 71 , no. 1 , p. $41-49$.
Peterson, J.A., and Clarke, J.W., 1983, Geology of the Volga-Ural petroleum province and detailed description of the Romashkino and Arlan oil fields: U.S. Geological Survey Open-File Report 83-711, 90 p.

Ulmishek, G.F., 1988, Upper Devonian-Tournaisian facies and oil resources of the Russian Craton's eastern margin: Canadian Society of Petroleum Geologists Memoir 14, p. 527-549.

Zaydelson, M.I., Surovikov, E.Ya., Vaynbaum, S.Ya., Bellerova, V.A., and Ashirov, K.B., 1991, Oil and gas potential of the Domanikoid associations of the Volga-Ural Province: International Geology Review, v. 33, no. 3, p. 243-262.

\section{Volga-Ural Region Province Assessment Team}

Timothy R. Klett, Michael E. Brownfield, Thomas M. Finn, Stephanie B. Gaswirth, Phuong A. Le, Heidi M. Leathers-Miller, Kristen R. Marra, Tracey J. Mercier, Janet K. Pitman, Christopher J. Schenk, Marilyn E. Tennyson, and Cheryl A. Woodall

\section{For More Information}

Assessment results are also available at the USGS Energy Resources Program website at https://energy.usgs.gov. 